\title{
Characteristics of Polish patients with systemic lupus erythematosus obtained from the SESAME registry. Activity of the disease, degree of impairment, and availability of social care
}

\author{
Charakterystyka polskich pacjentów chorych na toczen rumieniowaty układowy \\ na podstawie danych z rejestru SESAME. Aktywność choroby, stopień \\ niepetnosprawności i dostęp do pomocy spotecznej
}

\author{
Piotr Leszczyński ${ }^{1,2}$, Maria Majdan², Eugeniusz J. Kucharz ${ }^{4}$, Stanisław Sierakowski ${ }^{5}$, Piotr Wiland ${ }^{6}$, \\ Bartłomiej Kisiel7, Dominik Dziurda ${ }^{8}$, Tomasz Giemza ${ }^{8}$
}

Key words: SELENA SLEDAI score, SLE Activity Index, disability, social care.

Słowa kluczowe: SELENA SLEDAI score, indeks SLE, niepełnosprawność, pomoc społeczna.

\section{Summary}

The aim of the study was to characterize a large, and as homogeneous as possible, group of Polish patients with systemic lupus erythematosus (SLE). We focused on the sociodemographic characteristics of this group, clinical status at enrollment, and access to healthcare resources. Material and methods: The study included 269 consecutive patients from six Polish centers for rheumatology, in Bialystok, Katowice, Lublin, Poznań, Warsaw, and Wroclaw, qualified for the international multicenter study SESAME.

\section{Streszczenie}

Cel pracy: Charakterystyka grupy polskich chorych na toczeń rumieniowaty układowy (TRU). W opracowaniu skupiono się na charakterystyce społeczno-demograficznej tej grupy, obrazie klinicznym w chwili zakwalifikowania do badania oraz dostępie do pomocy spotecznej.

Materiał i metody: Badaniem objęto 269 kolejnych pacjentów z sześciu polskich ośrodków reumatologicznych: w Białymstoku, Katowicach, Lublinie, Poznaniu, Warszawie i Wrocławiu, zakwalifikowanych do mię-

Address for correspondence:

dr hab. med. Piotr Leszczyński, Department of Physiotherapy, Rheumatology and Rehabilitation, Poznan University of Medical Sciences, Szwajcarska 3, 61-285 Poznań, tel./fax +48 6187392 60, e-mail: piotr_leszczynski@wp.pl

Submitted: 22.05.2013 
Results: The majority of participants were women ( $n=234 ; 87 \%)$. Only $28.6 \%$ of SLE patients were employed full-time, and about one third of them received disability pension. The studied group included $12 \%$ of patients with at least a 6-point SELENA SLEDAI score, who showed a decreased level of complement and tested positively for anti-dsDNA antibodies. Patients whose SELENA SLEDAI scores exceeded 10 points (42\%) showed the active involvement of all sys tems and organs included in the SLE Activity Index, except for skin and mucosal membranes, with a significantly greater frequency than the other groups. The involvement of the musculoskeletal system was also significantly more frequent in patients with SELENA SLEDAI scores between 6 and 10 points (30.5\%). We observed a significant association between the activity of the disease and the prevalence of disability or having the support of a social worker.

Conclusions: The population of Polish patients with SLE includes a group of individuals who, due to high activity of the disease confirmed both by physical examination and additional testing, require intensification of the therapeutic protocol. This group can be identified on the basis of the SELENA SLEDAI score. Also, patients with severe disability are characterized by higher activity of the disease. It cannot be excluded that optimal therapeutic control of SLE activity in this group could be reflected by diminished demand for social care services and by a higher level of health-related quality of life.

\section{Introduction}

Systemic lupus erythematosus (SLE) is an autoimmune condition with a probably heterogeneous etiopathogenesis, unknown cause, and poorly understood pathogenesis. SLE can be associated with the involvement of virtually all systems and tissues, which is reflected by a variability of clinical symptoms; diagnosis of SLE is additionally hindered by heterogeneity of immunological parameters [1].

Epidemiological data, although inconclusive, suggest that the peak incidence of SLE occurs at relatively young age, at 29 years on average [2]. This corresponds to the risk of impairment in relatively young individuals, and preterm mortality [3]. Furthermore, obstetrical failures constitute an important complication of SLE due to high prevalence of this condition in young women [4].

Activity of the disease is a basic prognostic factor in SLE patients; also, the side effects of chronic corticosteroid therapy and immunosuppressive treatment should not be undervalued [5]. This is reflected by the necessity of offering specialist medical surveillance to SLE patients, as well as providing them proper access to healthcare resources. However, due to heterogeneous manifestation of the disease, the realization of this goal faces a number of obstacles. Firstly, data on SLE epidemiology are not collected on a routine dzynarodowego wieloośrodkowego badania SESAME, dotyczącego epidemiologii TRU w trzech krajach Europy Środkowej: w Rumunii, Polsce i na Węgrzech.

Wyniki: Wśród uczestników badania przeważały kobiety $(n=234 ; 87 \%)$. Zaledwie $28,6 \%$ chorych na TRU było zatrudnionych w pełnym wymiarze czasu pracy, a ok. 1/3 pobierała rentę zdrowotną. W badanej próbie znalazło się $12 \%$ chorych z SELENA SLEDAI score wynoszącym co najmniej 6 pkt, u których stwierdzono zmniejszone stężenie dopełniacza oraz obecność przeciwciał przeciw natywnemu DNA. U pacjentów, u których wartości SELENA SLEDAI score były wyższe niż 10 pkt (42\%), istotnie częściej niż w pozostałych grupach stwierdzano aktywne zajęcie wszystkich układów i narządów uwzględnionych w ocenie SLE Activity Index, z wyjątkiem skóry i błon śluzowych. Zajęcie układu mięśniowo-szkieletowego znamiennie częściej dotyczyło chorych o wartościach SELENA SLEDAI score mieszczących się w zakresie od 6 do 10 pkt (30,5\%). Zaobserwowano istotny związek pomiędzy wyższą aktywnością choroby a częstością występowania różnego stopnia niepełnosprawności oraz korzystaniem z pomocy pracownika socjalnego.

Wnioski: W populacji polskich chorych na TRU znajduje się grupa osób, które z uwagi na wysoką aktywność choroby potwierdzoną zarówno w badaniu klinicznym, jak i w badaniach laboratoryjnych wymagają intensyfikacji postępowania terapeutycznego. Wydaje się, że grupa ta może być identyfikowana na podstawie aktywności choroby określonej przy użyciu skali SELENA SLEDAI score. Znamiennie wyższą aktywnością choroby charakteryzują się również chorzy o znacznym stopniu niepełnosprawności. Nie można wykluczyć, że optymalna kontrola terapeutyczna aktywności TRU w tej grupie mogłaby przetożyć się na mniejsze zapotrzebowanie na świadczenia opieki spotecznej oraz na poprawę jakości życia.

basis. Secondly, patients with this condition are supervised by specialists in various medical disciplines, some of them not optimally prepared to perform complex therapy of connective tissue disorders. Thirdly, patients are most commonly hospitalized and treated due to organ complications rather than the underlying disorder, i.e. SLE. This is reflected by the underestimated number of Polish patients reported for statistical and epidemiological purposes.

The etiology of SLE is multifactorial. Continuous progress in clinical genetics allowed for the identification of many genetic risk factors of SLE; moreover, the phenotype of this condition is modulated by ethnic and geographic factors, among others $[6,7]$. In view of the considerations mentioned above, one should avoid broad generalizations in the epidemiological studies of SLE, and rather focus on the regional characteristics of the prevalence of this condition. However, searching through the available literature we did not find any published reports on the sociodemographic characteristics of Polish patients diagnosed with SLE, aside from those of 50 patients included in the European multicenter Euro-Lupus trial [2].

The aim of this study was to characterize a large, and as homogeneous as possible, group of Polish patients with SLE who were qualified for a multicenter non-interventional study. We focused on the sociodemographic characteris- 
tics of this group, clinical status at enrollment, and access to healthcare resources.

\section{Material and methods}

The study included Polish patients qualified for the international multicenter study SESAME (Systemic Lupus Erythematosus in CEE settings - Romania, Poland, Hungary; an insight on medical, economic and social burden), dealing with the epidemiology of SLE in three Central European countries: Romania, Poland and Hungary. The protocol of the study was approved by its sponsor (GSK Romania, protocol no. BEL115014), as well as by the Local Bioethical Committees of all clinical centers taking part in the project. All qualified patients gave their informed written consent to participate in the study.

The study, whose recruitment phase took place between April 30th, 2011 and the end of May 2012 in six Polish centers for rheumatology - in Bialystok, Katowice, Lublin, Poznań, Warsaw, and Wroclaw - included 269 consecutive patients diagnosed with SLE. The inclusion criteria of the study included completing 18 years of age, and currently or previously established diagnosis of SLE on the basis of the American College of Rheumatology 1997 classification criteria [8]. Simultaneous participation in any other clinical trial was the only exclusion criterion.

Basic sociodemographic characteristics of each patient were obtained during the enrollment visit, along with any obstetrical history of female patients. Moreover, the activ- ity of the disease was determined on the basis of the SELENA SLEDAI score and SLE Activity Index [9], as well as the degree of patient's impairment (mild, moderate, or severe). Prior to the study, all the researchers were trained in the use of the SELENA SLEDAI score and SLE Activity Index scales.

\section{Statistical analysis}

Normal distribution of continuous variables was verified with the Shapiro-Wilk test. Due to deviation from normal distribution, the statistical characteristics of continuous variables are presented as medians, interquartile intervals, and ranges. The statistical characteristics of discrete and qualitative variables are presented as number and percentage distributions. Values of continuous variables in two groups were compared with the Mann-Whitney U-test, while the Kruskal-Wallis test with Dunn post-hoc test was used for multiple comparisons. The Pearson's chisquare test or the Fisher exact test was used for the intergroup comparison of discrete or qualitative variable distributions. Power and direction of relationships between pairs of continuous variables were analyzed on the basis of Spearman's coefficient of rank correlation (R). Association between SELENA SLEDAI score and the degree of disability or the utilization of social care resources was verified in a univariate and multivariate model of logistic regression; odds ratios (ORs) were calculated, along with their $95 \%$ confidence intervals $(95 \% \mathrm{Cl}$ ). All calculations were

Table I. Sociodemographic characteristics of the study participants $(n=269)$

\begin{tabular}{|c|c|c|c|c|c|c|c|}
\hline \multirow[t]{2}{*}{ Variable } & \multicolumn{2}{|c|}{ Total } & \multicolumn{2}{|c|}{ Women } & \multicolumn{2}{|c|}{ Men } & \multirow[t]{2}{*}{$p$-value } \\
\hline & $n$ & $\%$ & $n$ & $\%$ & $n$ & $\%$ & \\
\hline \multicolumn{8}{|l|}{ Educational level } \\
\hline primary/grammar & 19 & 7.1 & 16 & 6.8 & 3 & 8.6 & 0.161 \\
\hline secondary & 131 & 48.7 & 119 & 50.9 & 12 & 34.3 & \\
\hline higher & 68 & 25.3 & 59 & 25.2 & 9 & 25.7 & \\
\hline other & 51 & 19.0 & 40 & 17.1 & 11 & 31.4 & \\
\hline \multicolumn{8}{|l|}{ Professional status } \\
\hline fulltime job & 77 & 28.6 & 65 & 27.8 & 12 & 34.3 & 0.699 \\
\hline part time job & 17 & 6.3 & 14 & 6.0 & 3 & 8.6 & \\
\hline unemployment pay & 11 & 4.1 & 10 & 4.3 & 1 & 2.9 & \\
\hline unemployed without pay & 9 & 3.3 & 8 & 3.4 & 1 & 2.9 & \\
\hline pupil/student & 14 & 5.2 & 14 & 6.0 & 0 & 0.0 & \\
\hline disability pension & 91 & 33.8 & 79 & 33.8 & 12 & 34.3 & \\
\hline retirement & 29 & 10.8 & 27 & 11.5 & 2 & 5.7 & \\
\hline other & 21 & 7.8 & 17 & 7.3 & 4 & 11.4 & \\
\hline
\end{tabular}


carried out with the Statistica 10 (StatSoft ${ }^{\circledR}$, Tulsa, OK, USA) package, with the level of significance set at $p \leq 0.05$.

\section{Results}

\section{Sociodemographic characteristics}

Our group included 269 patients, among them 268 (99.6\%) of Caucasian race. Median age of the studied group was 41 years (range 18-73 years; interquartile interval 32-53 years). The majority of participants were women ( $n=234 ; 87 \%$ ). Only $28.6 \%$ of SLE patients were employed full-time, and about one third of them received disability pension. The remaining sociodemographic characteristics of the studied group are presented in Table I.
Due to considerable representation of individuals receiving disability pension in our group ( $n=91 ; 33.8 \%$ ), we determined the statistical characteristics of age in this subgroup; the median age of disability pensioners was 43 years (range 24-64 years; interquartile interval 36-54 years).

\section{Clinical characteristics}

Median time after diagnosis of SLE in the studied patients was 7 years (range $0-39$ years; interquartile interval 3-13 years). Activity of the disease (SELENA SLEDAI score) was determined in 200 patients. Median SELENA SLEDAI score was 9 (range 1-59; interquartile interval 4-14.5). We did not document a significant correlation between the

Table II. Prevalence of SELENA SLEDAI indices in the studied group

\begin{tabular}{|c|c|c|c|c|c|c|c|}
\hline \multirow[t]{2}{*}{ Measure } & \multicolumn{2}{|c|}{ Total } & \multicolumn{2}{|c|}{ Women } & \multicolumn{2}{|c|}{ Men } & \multirow[t]{2}{*}{$p$-value } \\
\hline & $n$ & $\%$ & $n$ & $\%$ & $n$ & $\%$ & \\
\hline Seizure & 3 & 1.1 & 2 & 0.9 & 1 & 2.9 & 0.343 \\
\hline Psychosis & 5 & 1.9 & 3 & 1.3 & 2 & 5.7 & 0.128 \\
\hline Organic brain syndrome & 20 & 7.4 & 19 & 8.1 & 1 & 2.9 & 0.234 \\
\hline Visual disturbance & 11 & 4.1 & 10 & 4.3 & 1 & 2.9 & 0.569 \\
\hline Cranial nerve disorder & 2 & 0.7 & 2 & 0.9 & 0 & 0.0 & 0.756 \\
\hline Lupus headache & 16 & 5.9 & 16 & 6.8 & 0 & 0.0 & 0.100 \\
\hline Cerebrovascular accidents & 4 & 1.5 & 3 & 1.3 & 1 & 2.9 & 0.429 \\
\hline Vasculitis & 35 & 13.0 & 33 & 14.1 & 2 & 5.7 & 0.131 \\
\hline Arthritis & 97 & 36.1 & 85 & 36.3 & 12 & 34.3 & 0.487 \\
\hline Myositis & 30 & 11.1 & 27 & 11.5 & 3 & 8.6 & 0.430 \\
\hline Hematuria & 34 & 12.6 & 28 & 12.0 & 6 & 17.1 & 0.268 \\
\hline Urinary casts & 6 & 2.2 & 5 & 2.1 & 1 & 2.9 & 0.570 \\
\hline Pyuria & 22 & 8.2 & 19 & 8.1 & 3 & 8.6 & 0.567 \\
\hline Proteinuria & 39 & 14.5 & 33 & 14.1 & 6 & 17.1 & 0.397 \\
\hline Alopecia & 62 & 23.0 & 55 & 23.5 & 7 & 20.0 & 0.415 \\
\hline Skin lesions & 78 & 29.0 & 71 & 30.3 & 7 & 20.0 & 0.144 \\
\hline Mucosal ulcers & 16 & 5.9 & 16 & 6.8 & 0 & 0.0 & 0.100 \\
\hline Pleuritis & 8 & 3.0 & 8 & 3.4 & 0 & 0.0 & 0.323 \\
\hline Pericarditis & 11 & 4.1 & 8 & 3.4 & 3 & 8.6. & 0.160 \\
\hline Low complement & 52 & 19.3 & 45 & 19.2 & 7 & 20.0 & 0.534 \\
\hline Anti-dsDNA antibodies & 57 & 21.2 & 48 & 20.5 & 9 & 25.7 & 0.307 \\
\hline Fever & 20 & 7.4 & 18 & 7.7 & 2 & 5.7 & 0.502 \\
\hline Thrombocytopenia & 13 & 4.8 & 12 & 5.1 & 1 & 2.9 & 0.476 \\
\hline Leukopenia & 21 & 7.8 & 21 & 9.0 & 0 & 0.0 & 0.047 \\
\hline
\end{tabular}


Table III. Prevalence of decreased level of complement and/or anti-dsDNA antibodies in subgroups of patients with various activity of the disease $(n=200)$

\begin{tabular}{|c|c|c|c|c|c|c|c|}
\hline \multirow[t]{3}{*}{ Parameter } & \multicolumn{6}{|c|}{ Activity of the disease (SELENA SLEDAI score) } & \multirow[t]{3}{*}{$p$-value } \\
\hline & \multicolumn{2}{|c|}{$<6(n=55)$} & \multicolumn{2}{|c|}{$6-10(n=61)$} & \multicolumn{2}{|c|}{$>10(n=84)$} & \\
\hline & $n$ & $\%$ & $n$ & $\%$ & $n$ & $\%$ & \\
\hline Decreased complement & 15 & 27.3 & 18 & 29.5 & 19 & 22.6 & 0.626 \\
\hline Anti-dsDNA antibodies & 13 & 23.6 & 24 & 39.3 & 20 & 23.8 & 0.079 \\
\hline $\begin{array}{l}\text { Decreased complement } \\
\text { and anti-dsDNA antibodies }\end{array}$ & 6 & 10.9 & 10 & 16.4 & 14 & 16.7 & 0.607 \\
\hline
\end{tabular}

Table IV. Prevalence of active involvement or injury of various organs/systems determined on the basis of SLE Activity Index $(n=269)$

\begin{tabular}{|lcccc|}
\hline Organ/system & \multicolumn{2}{c}{$\begin{array}{c}\text { Active } \\
\text { involvement }\end{array}$} & \multicolumn{2}{l|}{ Injury } \\
\cline { 2 - 5 } & $n$ & $\%$ & $n$ & $\%$ \\
\hline Cardiovascular system & 15 & 5.6 & 26 & 9.7 \\
\hline Hematopoietic system & 38 & 14.1 & 16 & 5.9 \\
\hline $\begin{array}{l}\text { Mucosal membranes } \\
\text { and skin }\end{array}$ & 55 & 20.4 & 19 & 7.1 \\
\hline Musculoskeletal system & 76 & 28.3 & 23 & 8.6 \\
\hline Nervous system & 25 & 9.3 & 32 & 11.9 \\
\hline Kidneys & 53 & 19.7 & 32 & 11.9 \\
\hline Respiratory tract & 11 & 4.1 & 17 & 6.3 \\
\hline Blood vessels & 22 & 8.2 & 13 & 4.8 \\
\hline
\end{tabular}

activity of the disease and the age of patients $(R=0.02$; $p=0.803$ ) or time after diagnosis $(\mathrm{R}=-0.1 ; p=0.166)$. Furthermore, there were no significant gender-related differences in the median duration of SLE (women: 4 years [1-11], men: 8 years [3-13], $p=0.071$ ) and median SELENA SLEDAI score (women: 9 [6-15], men: 8 [4-14], $p=0.231$ ).

The prevalence of clinical and laboratory features included in the SELENA SLEDAI scale in the studied group is presented in Table II. The most frequently observed features included arthritis and skin lesions, and the least prevalent ones were cranial nerve disorders, seizures, cerebrovascular accidents, and psychoses. The only genderrelated difference in the prevalence of symptoms included in SELENA SLEDAI, which came close to statistical significance, referred to leukopenia, observed solely in women.

The studied group included 24 patients (12\%) with at least a 6-point SELENA SLEDAI score, who had a decreased level of complement and were tested positively for antidsDNA antibodies. Subgroups of patients with various activity of the disease (SELENA SLEDAI score below 6, between 6 and 10 , and above 10 points) did not differ significantly in terms of the presence of low complement and/or antidsDNA antibodies (Table III).

Our patients most frequently showed active involvement of the musculoskeletal system and skin, while the respiratory and cardiovascular systems were least frequently involved. In turn, organic injuries were most common in kidneys and the nervous system (Table IV). We did not observe a significant effect of patient gender on the prevalence of active involvement or injury of various systems/organs.

The group of patients whose SELENA SLEDAI scores exceeded 10 points showed the active involvement of all systems and organs included in the SLE Activity Index, except for skin and mucosal membranes, with a significantly greater frequency than the other groups. The involvement of the musculoskeletal system was significantly more frequent in patients with SELENA SLEDAI scores between 6 and 10 points (Table $\mathrm{V}$ ).

\section{Obstetric failures}

Our group included 114 women with documented obstetric history, among them 35 (30.7\%) with a history of obstetric failures: spontaneous miscarriage $(n=32)$, pregnancy termination $(n=2)$, or miscarriage/pregnancy termination $(n=1)$. Thirteen patients had a history of more than one miscarriage, namely two $(n=10)$, three $(n=2)$, or four $(n=1)$.

Overall, there were 55 cases (22\%) of failure among 250 pregnancies documented in the studied group, among them 49 due to spontaneous miscarriage, and 6 associated with the necessity of pregnancy termination.

At enrollment in the study, patients with a history of obstetric failures did not differ significantly from the remaining women in terms of median SELENA SLEDAI score (8 [4-12] vs. 8 [4-12] respectively, $p=0.902$ ). 
Table V. Prevalence of active involvement of various organs/systems determined on the basis of SLE Activity Index in subgroups of patients with various activity of the disease $(n=200)$

\begin{tabular}{|c|c|c|c|c|c|c|c|}
\hline \multirow[t]{3}{*}{ Organ/system } & \multicolumn{6}{|c|}{ Activity of the disease (SELENA SLEDAI score) } & \multirow[t]{3}{*}{$p$-value } \\
\hline & \multicolumn{2}{|c|}{$<6(n=55)$} & \multicolumn{2}{|c|}{$6-10(n=61)$} & \multicolumn{2}{|c|}{$>10(n=84)$} & \\
\hline & $n$ & $\%$ & $n$ & $\%$ & $n$ & $\%$ & \\
\hline Cardiovascular system & 1 & 1.8 & 1 & 1.6 & 9 & $10.7^{*}$ & 0.023 \\
\hline Hematopoietic system & 5 & 9.1 & 7 & 11.5 & 21 & $25.0^{\star}$ & 0.021 \\
\hline Mucosal membranes and skin & 11 & 20.0 & 20 & 32.8 & 22 & 26.2 & 0.296 \\
\hline Musculoskeletal system & 8 & 14.5 & 32 & $52.5^{\star}$ & 31 & $36.9^{\star}$ & $<0.001$ \\
\hline Nervous system & 1 & 1.8 & 4 & 6.6 & 17 & $20.2^{\star}$ & 0.001 \\
\hline Kidneys & 7 & 12.7 & 10 & 16.4 & 30 & $35.7^{\star}$ & 0.002 \\
\hline Respiratory tract & 1 & 1.8 & 0 & 0.0 & 8 & $9.5^{*}$ & 0.013 \\
\hline Blood vessels & 1 & 1.8 & 1 & 1.6 & 19 & $22.6^{*}$ & $<0.001$ \\
\hline
\end{tabular}

*Significantly more frequently than in the remaining subgroups $(p \leq 0.05)$

\section{Degree of disability}

The analyzed group included 101 (37.5\%) individuals with various degrees of disability, among them 56 (20.8\%) patients with mild, 35 (13\%) with moderate, and 10 (3.7\%) with severe disability. Eleven patients (4.1\%) had the support of a social worker. We observed a significant asso-

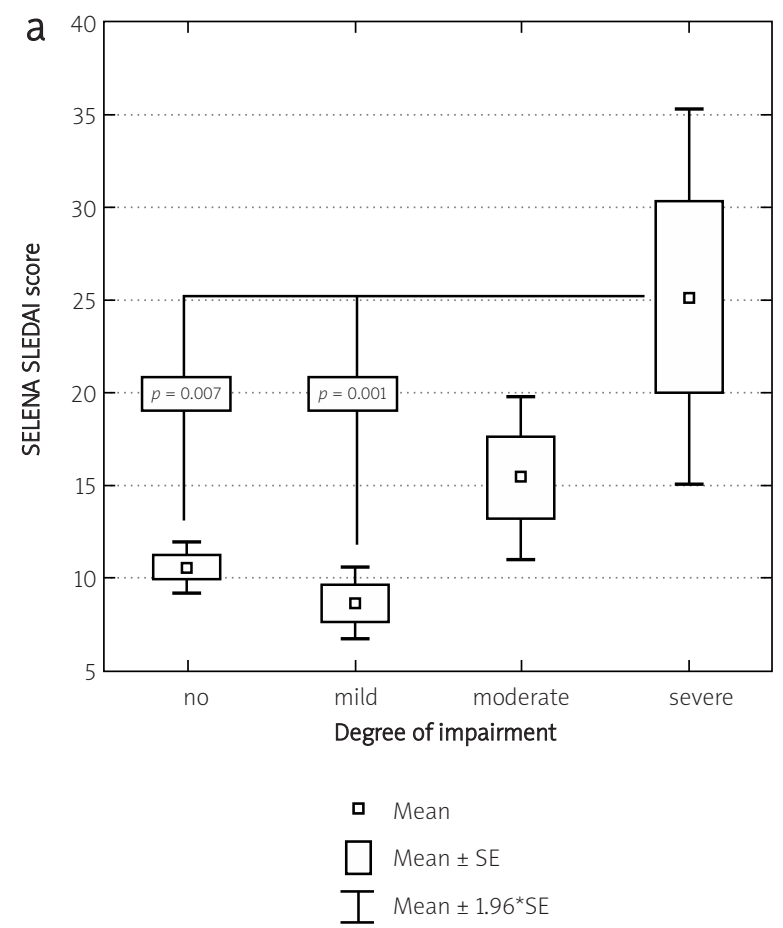

ciation between the activity of the disease and the prevalence of disability of various degree or having the support of a social worker (Fig. 1a, b). In contrast, we did not reveal any significant differences in SELENA SLEDAI score, associated with the fact of obtaining disability pension $(p=0.567)$.

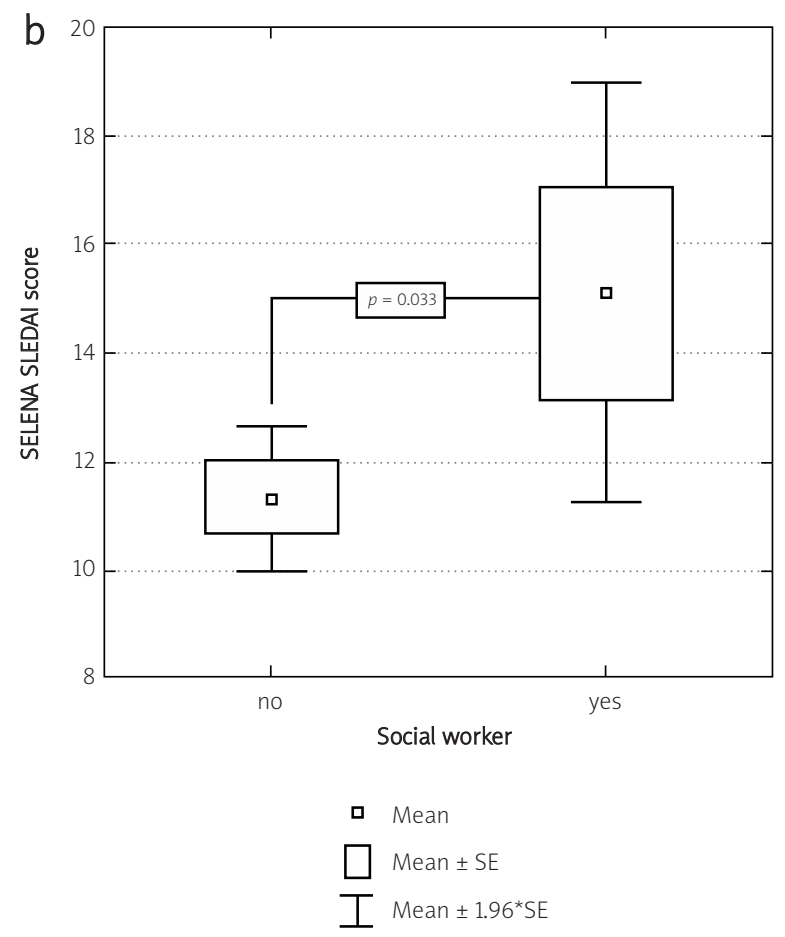

Fig. 1. SELENA SLEDAI score depending on the degree of disability (a) or having the support of a social worker (b). 
Univariate analysis of logistic regression revealed that at enrollment in the study individuals with moderate or severe disability differed from the remaining patients in terms of significantly higher prevalence of the following signs included in the SELENA SLEDAI score: visual disturbance $(\mathrm{OR}=15.9,95 \% \mathrm{Cl}: 4.0-63.2, p<0.001)$, cerebrovascular accidents $(\mathrm{OR}=15.9,95 \% \mathrm{Cl}: 1.6-158.5$, $p=0.018)$, organic brain syndromes $(\mathrm{OR}=4.8,95 \% \mathrm{Cl}$ : $1.9-12.6, p=0.001)$, mucosal ulcers $(\mathrm{OR}=4.4,95 \% \mathrm{Cl}$ : $1.5-12.6, p=0.006)$, myositis $(\mathrm{OR}=3.5,95 \% \mathrm{Cl}: 1.5-8.0$, $p=0.003)$, proteinuria $(\mathrm{OR}=2.7,95 \% \mathrm{Cl}: 1.2-5.8, p=0.013)$, and vasculitis ( $\mathrm{OR}=2.3,95 \% \mathrm{Cl}: 1.0-5.2, p=0.049)$. In contrast, individuals with a severe or moderate degree of disability did not differ significantly from the remaining patients in the prevalence of active involvement or injury of organs/systems included in the SLE Activity Index. The multivariate analysis of logistic regression identified visual disturbance $(\mathrm{OR}=9.2,95 \% \mathrm{Cl}: 1.7-48.2, p=$ $=0.009)$ and proteinuria $(\mathrm{OR}=2.4,95 \% \mathrm{Cl}: 1.0-5.6, p=0.044)$ as significant independent determinants of severe or moderate disability.

Higher degree of disability was associated with significantly higher frequency of receiving disability pension $(p<0.001)$. This type of social support was received by $7 / 10$ (70\%) patients with severe disability, 18/35 (51.4\%) with moderate disability, 32/56 (57.1\%) with mild disability, and 34/168 (20.2\%) fully-capable individuals. The univariate analysis of logistic regression showed that at enrollment in the study patients receiving disability pension differed from the remaining subjects solely in terms of significantly higher prevalence of mucosal ulcers $(\mathrm{OR}=3.5,95 \% \mathrm{Cl}$ : $1.2-10.1, p=0.018)$

\section{Discussion}

\section{Demographic and clinical characteristics}

The non-interventional study constituting the basis for selecting our sample included patients who met at least four American College of Rheumatology classification criteria [8]; the demographic characteristics of the sample thus selected were similar as in other epidemiological studies. Our group included 13\% men. According to current knowledge, the prevalence of SLE among men is approximately 10 times lower than in women. According to a recently published review of the literature, men represent from $4 \%$ to $22 \%$ of SLE patients; however, this percentage can increase up to 30\% in the case of familial aggregation of SLE [10]. Similar evidence originates from recent epidemiological studies conducted in European countries. The percentage of male patients amongst the participants of the European multicenter Euro-Lupus trial was 9\% [2], and in another multicenter European study was 11\% [11]. However, the studies covering smaller administrative areas produced more variable results: in a population-based study of a representative sample of nearly 26000 Sardinia inhabitants there were no male patients with SLE (compared to 148 female cases) [12], in Croatia men corresponded to $10.5 \%$ of all 162 SLE patients [13], in Southern France to $15 \%(n=6 / 41)$ [7], and in Porto (Portugal) to as many as $36.4 \%[14]$.

The results of many studies suggest that exposure to endogenous estrogens, resulting from the overexpression of estrogen receptor- $\alpha$, is a main factor responsible for higher prevalence of SLE in women [15]. However, although in animal models the course of SLE is more severe in females [16], most epidemiological studies revealed the inverse association in humans [17]. The previously mentioned Euro-Lupus study revealed that at the diagnosis of SLE men more frequently show serositis, but in the course of fully symptomatic disease they suffer from arthritis less frequently than women [2]. Other studies showed higher prevalence of kidney involvement and failure in men [18, 19], as well as higher frequency of thromboembolic episodes [18]. Also the results of studies conducted outside Europe suggest that the manifestation of SLE is more severe in male patients [17]. Worse prognosis in men with SLE was attributed to the lack of protective effect of estrogens against organ injury [20], and stimulatory influence of androgens on the processes of apoptosis [21].

We did not observe any significant gender-related differences in the prevalence of SLE-specific organic lesions or the activity of the disease. It is very likely that this lack of gender-related differences did not result from the confounding effect of any clinical variables, as there was no correlation between the time elapsed after diagnosis and SELENA SLEDAI score, and the duration of the disease in men and women was comparable.

Also in previous European studies of SLE patients the gender-specific differences in the activity of the disease were not so evident as on other continents [17]. Therefore, one can suppose that ethnic background along with related genetic predisposition represents a factor determining the outcome of SLE. This hypothesis was at least partially confirmed by the results of previous epidemiological studies. The Euro-Lupus study revealed that European patients, the majority of whom are Caucasians, are characterized by a lower frequency of the organ manifestation of SLE compared to patients from Asia, and North and South America $[2,6]$. This observation was also confirmed by other authors [5, 22]. Moreover, the results of another multicenter European study [11] suggest that the activity of SLE can also differ within the same continent. This study showed that patients from southern Europe were characterized by significantly lower SLEDAI scores than individuals from other countries [11].

Also the time elapsed from diagnosis is vital for the activity of SLE. According to Urowitz et al. [5], the activity of the 
disease decreases markedly and stabilizes within the initial five years after diagnosis. Furthermore, it was observed that the activity of SLE in Caucasian patients decreases earlier than in individuals of other races [22]. Although it was not confirmed by the analysis of correlation, perhaps it was the relatively long time after diagnosis of SLE (median 7 years, interquartile range $3-13$ years) which was reflected by the relatively low activity of the disease in our patients (median SELENA SLEDAI score equal to 9). In contrast, in one multicenter European study, the mean SLEDAI-2K score of 200 patients who were diagnosed with SLE at an average age of 34.8 years was 12.2. However, it should be noted that the activity of the disease in this group was determined earlier than in our patients, i.e. 28 months after diagnosis on average [11].

The spectrum of clinical changes observed in our patients was similar to that previously described in multicenter European studies [2, 11]. Similar to our patients, arthritis and skin lesions were the most frequent abnormalities documented among the participants of these studies. However, they were observed markedly more frequently (arthritis: 48.1-69\%, skin lesions: $31.1-53 \%$ ) than in our group (36.1\% and $29 \%$, respectively). Probably, also these differences could be attributed to the homogeneous ethnic background of our group (nearly 100\% Caucasians) and longer duration of disease, promoting its attenuation.

Nevertheless, it should be noted that in our group in $12 \%$ of patients high activity of the disease (SELENA SLEDAI score $\geq 6$ points) coexisted with the presence of anti-dsDNA antibodies and a low level of complement. Moreover, patients with a SELENA SLEDAI score above 10 points significantly more frequently showed the active involvement of most organs. These findings suggest that the population of patients with SLE includes a group of individuals who, due to high activity of the disease confirmed both by physical examination and additional testing, require intensification of the therapeutic protocol. Moreover, the results of our study suggest that this group can be identified on the basis of the SELENA SLEDAI score.

\section{Obstetric failures}

Our study revealed failure of $22 \%$ of pregnancies in SLE patients. This observation is consistent with literature evidence: according to recent reports, the prevalence of obstetric failures among SLE patients does not exceed 23\% [23]. Marked improvement in this matter was documented during the last two decades, as before 1990 the percentage of live births in SLE patients was more than 10\% lower than nowadays [24]. Nevertheless, in many cases pregnancy has to be terminated preterm due to SLE-specific complications; this was reflected by the significant increase in the number of preterm births among SLE patients, from 19.1\% to
$24.5 \%$, that was documented during the last two decades [24]. The most frequent complications observed in pregnant patients with SLE include preeclampsia, thromboembolic episodes, infections, and thrombocytopenia with susceptibility to bleeding [25].

Our patients with a history of obstetric failure did not differ significantly from the remaining women in terms of the activity of SLE determined on the basis of the SELENA SLEDAI score. In turn, the active stage of the disease constitutes a documented risk factor of obstetric failure [25-27]. However, it should be remembered that we analyzed obstetric histories retrospectively, and thus SELENA SLEDAI scores documented in our patients did not reflect the activity of the disease at conception and pregnancy.

Although the prevalence of obstetric failure in our group did not differ markedly from data reported in the literature, it should be remembered that we did not collect information on birth weight and other indices of fetal/neonatal wellbeing. In turn, these parameters also constitute important indicators of the optimal obstetric care for SLE patients $[4,28]$.

\section{Degree of disability in SLE patients}

Our study revealed that nearly $40 \%$ of Polish patients with SLE show various degrees of disability, and approximately one-third of them receive a disability pension. Statistical analysis confirmed that the degree of disability determines the accessibility of social care for individuals with SLE. However, although we documented a significant association between the activity of the disease and the degree of disability, we failed to confirm that individuals obtaining a disability pension were characterized by higher activity of the disease determined on the basis of the SELENA SLEDAI score. Probably, this resulted from the fact that the activity of the disease was determined post factum rather than at the time of being granted the pension.

Social support should play a crucial role in the complex therapy of SLE patients. This was confirmed by a review of previous studies dealing with the problem in question, conducted by Mazzoni and Cicognani [29]. These authors revealed that various forms of social support, including psychological counseling and behavioral therapy, play a vital role not only in the context of higher quality of life in SLE patients, but also with regards to the degree of disease activity and organ injuries. We did not analyze the availability of this type of support to our patients; nevertheless, our empiric experiences suggest that it is low. This was also confirmed in a large study of Polish patients with rheumatoid arthritis, in which $95 \%$ of participants reported the feeling of social exclusion [30].

High prevalence of disability among patients with SLE is undoubtedly associated with a significant financial bur- 
den on the Polish social care system. In this context, our finding of a significant relationship between the activity of the disease and the degree of disability seems worth noting. We revealed that patients with severe disability are characterized by significantly higher SELENA SLEDAI scores. Therefore, one could ask if optimal therapeutic control of SLE activity would not be reflected by diminished demand for social care services. This raises further questions on the cost effectiveness of healthcare and social care services and their influence on health-related quality of life.

\section{Strengths and limitations of the study}

The large size of our group, as well as unified inclusion criteria, homogeneous ethnic background, and completeness of data, represent unquestionable strengths of this study. One potential limitation pertains to the retrospective character of some data, as it hindered verification of their relationship to the activity of the disease at enrollment. Nevertheless, we did our best to adjust for this potential confounder during the interpretation of our findings.

\section{Conclusions}

1. The population of Polish patients with SLE includes a group of individuals who, due to high activity of the disease confirmed both by physical examination and additional testing, require intensification of the therapeutic protocol. Our findings suggest that this group can be identified on the basis of the SELENA SLEDAI score.

2. Also, patients with severe disability are characterized by higher activity of the disease. Therefore, it cannot be excluded that optimal therapeutic control of SLE activity in this group could be reflected by diminished demand for social care services and a higher level of health-related quality of life.

\section{Acknowledgements}

The authors would like to acknowledge the remaining researchers who were involved in the realization of SESAME in Poland. These are (in alphabetical order): Dr Arkadiusz Chlebicki (Wroclaw), Dr Katarzyna Chmielewska (Poznan), Dr Magdalena Dryglewska (Lublin), Dr Ewa Dudziec (Poznan), Dr Katarzyna Gruszecka (Wroclaw), Dr Ewelina Jastrzębska (Bialystok), Zofia Kiełbik MSc (Lublin), Dr Mateusz Kokot (Poznan), Dr Anna Kotulska (Katowice), Dr Bożena Kowalewska (Wroclaw), Dr Justyna Kramza (Katowice), Dr Ewa Krecipro-Nizińska (Wroclaw), Dr Joanna Kur-Zalewska (Warsaw), Dr Anna Łuczak (Wroclaw), Dr Mateusz Łukaszyk (Bialystok), Dr Marta Madej (Wroclaw), Dr Katarzyna Pawlak-Buś (Poznan), Dr Eliza Roszkowska (Wroclaw), Dr Dorota Suszek (Lublin), Dr Tomasz Szafrański (Poznan), Dr Małgorzata Szarzyńska-Ruda (Katowice), Dr Magdalena Szmyrka-Kaczmarek (Wroclaw), Prof. Witold Tłustochowicz (Warsaw), Dr Patryk Woytala (Wroclaw), and Dr Marek Zawadzki (Wroclaw).
Authors declare no conflict of interest.

Moreover, the authors would like to acknowledge the editorial and linguistic support of SciencePro company (Warsaw).

\section{References}

1. Firestein GS, Budd RC, Gabriel SE, et al. Kelley's Textbook of Rheumatology $9^{\text {th }}$ ed., Saunders 2013.

2. Cervera R, Khamashta MA, Hughes GR. The Euro-lupus project: epidemiology of systemic lupus erythematosus in Europe. Lupus 2009; 18: 869-874.

3. Bernatsky S, Boivin JF, Joseph L, et al. Mortality in systemic lupus erythematosus. Arthritis Rheum 2006; 54: 2550-2557.

4. Canti V, Castiglioni MT, Rosa S, et al. Pregnancy outcomes in patients with systemic autoimmunity. Autoimmunity 2012; 45: 169-175.

5. Urowitz MB, Gladman DD, Ibanez D, et al. Evolution of disease burden over five years in a multicenter inception systemic lupus erythematosus cohort. Arthritis Care Res (Hoboken) 2012; 64: 132137.

6. Cervera R, Abarca-Costalago M, Abramovicz D, et al. Systemic lupus erythematosus in Europe at the change of the millennium: lessons from the "Euro-Lupus Project". Autoimmun Rev 2006; 5: 180186.

7. Chiche L, Jourde N, Ulmann C, et al. Seasonal variations of systemic lupus erythematosus flares in southern France. Eur J Intern Med 2012; 23: 250-254.

8. Guidelines for referral and management of systemic lupus erythematosus in adults. American College of Rheumatology Ad Hoc Committee on Systemic Lupus Erythematosus Guidelines. Arthritis Rheum 1999; 42: 1785-1796.

9. Griffiths B, Mosca M, Gordon C. Assessment of patients with systemic lupus erythematosus and the use of lupus disease activity indices. Best Pract Res Clin Rheumatol 2005; 19: 685-708.

10. Lu LJ, Wallace DJ, Ishimori ML, et al. Review: Male systemic lupus erythematosus: a review of sex disparities in this disease. Lupus 2010; 19: 119-129.

11. Nossent J, Kiss E, Rozman B, et al. Disease activity and damage accrual during the early disease course in a multinational inception cohort of patients with systemic lupus erythematosus. Lupus 2010; 19: 949-956.

12. Sardu C, Cocco E, Mereu A, et al. Population based study of 12 autoimmune diseases in Sardinia, Italy: prevalence and comorbidity. PLoS One 2012; 7: e32487.

13. Cerovec M, Anic B, Padjen I, et al. Prevalence of the American College of Rheumatology classification criteria in a group of 162 systemic lupus erythematosus patients from Croatia. Croat Med J 2012; 53: 149-154.

14. Monjardino T, Lucas R, Barros H. Frequency of rheumatic diseases in Portugal: a systematic review. Acta Reumatol Port 2011; 36: 336-363.

15. Shoenfeld Y, Tincani A, Gershwin ME. Sex gender and autoimmunity. J Autoimmun 2012; 38: J71-73.

16. Mok CC, Lau CS, Chan TM, et al. Clinical characteristics and outcome of southern Chinese males with systemic lupus erythematosus. Lupus 1999; 8: 188-196. 
17. Schwartzman-Morris J, Putterman C. Gender differences in the pathogenesis and outcome of lupus and of lupus nephritis. Clin Dev Immunol 2012; 2012: 604892.

18. Stefanidou S, Benos A, Galanopoulou V, et al. Clinical expression and morbidity of systemic lupus erythematosus during a postdiagnostic 5-year follow-up: a male:female comparison. Lupus 2011; 20: 1090-1094.

19. Voulgari PV, Katsimbri P, Alamanos Y, et al. Gender and age differences in systemic lupus erythematosus. A study of $489 \mathrm{Greek}$ patients with a review of the literature. Lupus 2002; 11: 722-729.

20. Grzegorczyk K, Krajewska M, Weyde W, et al. [Gender and kidney diseases: the clinical importance and mechanisms of modifying effects]. Postepy Hig Med Dosw (Online) 2011; 65: 849-857.

21. Gandolfo MT, Verzola D, Salvatore F, et al. Gender and the progression of chronic renal diseases: does apoptosis make the difference? Minerva Urol Nefrol 2004; 56: 1-14.

22. Zhang J, Gonzalez LA, Roseman JM, et al. Predictors of the rate of change in disease activity over time in LUMINA, a multieth nic US cohort of patients with systemic lupus erythematosus: LUMINA LXX. Lupus 2010; 19: 727-733.

23. Marker-Hermann E, Fischer-Betz R. Rheumatic diseases and pregnancy. Curr Opin Obstet Gynecol 2010; 22: 458-465.

24. Yan Yuen S, Krizova A, Ouimet JM, et al. Pregnancy outcome in systemic lupus erythematosus (SLE) is improving: Results from a case control study and literature review. Open Rheumatol J 2008; 2: 89-98.

25. Clowse ME, Magder LS, Witter F, et al. The impact of increased lupus activity on obstetric outcomes. Arthritis Rheum 2005; 52 514-521.

26. Petri M. Prospective study of systemic lupus erythematosus pregnancies. Lupus 2004; 13: 688-689.

27. Wei Q, Ouyang Y, Zeng W, et al. Pregnancy complicating systemic lupus erythematosus: a series of 86 cases. Arch Gynecol Obstet 2011; 284: 1067-1071.

28. Chen CY, Chen YH, Lin HC, et al. Increased risk of adverse pregnancy outcomes for hospitalisation of women with lupus during pregnancy: a nationwide population-based study. Clin Exp Rheumatol 2010; 28: 49-55.

29. Mazzoni D, Cicognani E. Social support and health in patients with systemic lupus erythematosus: a literature review. Lupus 2011; 20: 1117-1125.

30. Bugajska J, Brzosko M, Jedryka-Goral A, et al. Psychological stress in rheumatoid arthritis patients: a comparative Polish-German study: summary of the current conceptualization of the role of stress in rheumatoid arthritis. Autoimmun Rev 2010; 9: 211-215. 